\title{
INSTITUTEAFFAIRS
}

Canadian Institute of Forestry

Institut Forestier du Canada

Suite 1005, 151 Slater St.

Ottawa, Ontario, Canada K1P 5H3

Tel. (613) 234-2242

Fax. (613) 234-6181

President/Président - A. Rotherham 1st Vice-President/1er vice-président P.J. Murphy

2nd Vice-President/2ème vice-président H. Oldham

Past President/Président sortant A. Whidden

Executive Director/directeur exécutif C.A. Lee

Directors/directeurs

J. Monty, Algonquin, R.L. Macnaughton, Central Ontario, J. Dojack, Manitoba, P. Etheridge, Maritime, P. Street, Northwestern Ontario, Rod Willis, Okanagan, F. Julien, Orleans, R. Lipman, Ottawa Valley, Cindy Fox, Pacific, I. Corns, Rocky Mountain, A.D. Wynia, Southern Ontario, G. Taylor, Vancouver.

Section Chairs/president du section Ed Stechishen, Algonquin, Keith McClain, Cariboo, Keith Dufresne, CaribooChilcotin, J. Jeglum, Central Ontario, Jean-Marc Lacasse, Champlain, Colin Hewitt, Lake of the Woods, Bob Yatkowsky, Manitoba, T. Needham, Maritime, D. Bajzak, Newfoundland, Rob Galloway, Northern Ontario, Jack Flowers, Northwestern Ontario, R. Archibald, Nova Scotia, Don Couch, Okanagan, J.P. Dansereau, Orleans, Jean-Louis Wallace, Ottawa Valley, Mike Dietsch, Pacific, Thor Knapp, Rocky Mountain, David Lindenas, Saskatchewan, Bill Camerzind, Skeena, Bruce Ferguson, Southern Ontario, Greg Taylor, Vancouver, Art Walker, Vancouver Island.

Forest Science and Technology Board Comité des sciences et technologies forestières

Peter Marshall, Chair/président, Pierre Bernier, Past Chair/président sortant, C.A. Lee, Secretary/secrétaire, Glen Blouin, For. educ., D. Brand, Silv. and tree imp., Victor Brunette, Private for., Jan Volney, For. pest management, John Hall, International for., A. Harestad, Wildlife and fish hab., G. Huntley, Urban for., Valerie LeMay, For. measurement, T. Williamson, For. econ. and policy, E. McGurk, For. hydrology, A. Sinclair, For. harvesting.

\section{The Executive Director Reports}

People often ask what we do at the National Office of CIF/IFC and if the money they pay to be a member is worthwhile. I have reported on our major activities and am preparing a detailed report on the work undertaken under the Action Plan for 1992-93, but there is more to this office than just those items.

We often get requests about employment, education, forestry issues and other things and we respond as quickly and as best we can. Some of these specific requests and activities are worth mentioning. Revenue Canada has a panel which advises them on research activities and tax implications and benefits for those conducting research. They wanted to include those involved in forest research and came to us for a list of possible candidates. We were able to give them the names of five excellent candidates from across the country.

The German Embassy in Washington recently established a forestry attache. He wanted to learn more about forestry in Canada and called CIF/IFC. We established an excellent contact and when the Embassy needed help in putting together a panel of NGOs to discuss forestry with members of the German Parliament, they again called us. We set up the meeting and again furthered our reputation and the cause of forestry with the German Parliament.

The National Forest Strategy Coalition was recently setting up committees to handle various tasks involved in implementing and monitoring the Strategy. They wanted the voice of foresters on the communications and evaluations committees. They called CIF/IFC and we gladly agreed. The concerns of the practitioners who are charged with implementing the Strategy's recommendations are now well represented.

The Forest Research Advisory Council of Canada was set up several years ago to offer advice and direction to Forestry Canada of its research programs. CIF/IFC has been a member of that organization for several years and our voice is sought after and listened to.

When External Affairs wanted to know about the qualifications for foresters coming to Canada from offshore they contacted us. Through contacts at the RPF Associations, we put together a suitable response to their request which was linked to trade in services under the Free Trade Agreement and to Canada's participation in GATT.

Elections Canada wishes to let Canadians working off-shore know that they can register to vote in the upcoming federal election. They called CIF/IFC so that we could contact our members offshore.

Most recently, the RPF Associations and CIF/IFC felt we should get together and discuss future forestry agreements following the federal government's recent decision to get out of federal-provincial forestry agreements. We also wanted to discuss the new Natural Resources Department and the upcoming federal election. The CIF/IFC organized a conference call in which all five RPF Associations and CIF/IFC had their Presidents and/or Executive Directors on the line. We agreed to write to the Prime Minister and the new Minister Designate of Natural Resources expressing our concerns with respect to the forestry agreements and we are preparing an election package for use by all members to make forestry an issue in the next election.

These are a few of the specific examples of how your support and membership pays off in action for forestry. I hope your support will continue.

C.A. Lee, R.P.F. Executive Director 